Who Prices Locally?

Survey Evidence of Swiss Exporters

Andreas M. Fischer, Matthias Lutz and Manuel Wälti

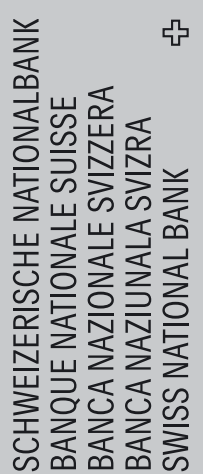

U

(2)

0

(

0

.

ro

a 
The views expressed in this paper are those of the author(s) and do not necessarily represent those of the Swiss National Bank. Working Papers describe research in progress. Their aim is to elicit comments and to further debate.

ISSN $1660-7716$

๑ 2007 by Swiss National Bank, Börsenstrasse 15, P.0. Box, CH-8022 Zurich 


\title{
Who Prices Locally? Survey Evidence of Swiss Exporters*
}

\author{
Andreas M. Fischer ${ }^{\dagger}$ \\ Matthias Lutz \\ Manuel Wälti ${ }^{\S}$
}

August 15, 2007

\begin{abstract}
Survey information on Swiss exporters is used to test the hypothesis that firm-specific factors, in particular firm size, are important determinants of pricing-to-market (PTM). The survey asked exporters whether they set different prices across markets and, if so, whether price segmentation occurred because of pricing conditions in the local market or other factors. The empirical analysis is based on a probit model that regresses a binary-choice variable of PTM on firm size and other control variables. The main empirical finding is that firm size and PTM are positively and significantly correlated. A further result is that while firms whose main export market is in the Euro area are less likely to engage in PTM, firm size plays a bigger role for them. These results are robust across different PTM classifications, regression specifications, export destinations, and industrial sectors.
\end{abstract}

JEL classifications: F10, F14

Keywords: Pricing to markets, local currency pricing, firm size.

${ }^{*}$ The authors would like to thank Raphael Auer, Philippe Bacchetta, Stefan Betschart, Ibrahim Chowdhury, Richard Etter, Richard Friberg, Thomas Mathä, Christoph Siepmann and an anonymous refereee for helpful comments and discussions. The views expressed here are those of the authors, and do not necessarily reflect the position of the Swiss National Bank.

${ }^{\dagger}$ Swiss National Bank and CEPR, International Research, Postfach, 8022 Zurich, Switzerland, Tel. (+41 44) 63132 94, Fax (+41 44) 63181 72, andreas.fischer@snb.ch.

${ }^{\ddagger}$ Swiss National Bank and University of St. Gallen, International Monetary Relations, Postfach, 8022 Zurich, Switzerland, Tel. (+41 44) 63136 19, Fax (+41 44)63181 72, matthias.lutz@snb.ch.

${ }^{\S}$ Swiss National Bank, Economic Analysis, Postfach, 8022 Zurich, Switzerland, Tel. (+41 44) 63138 26, Fax (+41 44) 63181 72, manuel.waelti@snb.ch. 


\section{Introduction}

Do firm-specific factors explain why some companies price-discriminate across export markets and others do not? Two decades of micro-based theoretical research in international macroeconomics has shown that our thinking on crucial issues like the desirability of fixed versus flexible exchange rates can be strongly influenced by specific assumptions about the price-setting behavior of firms. ${ }^{1}$ Traditional empirical research, however, has primarily emphasized country- and sector-specific factors to explain international price discrimination (Goldberg and Knetter 1997). This paper, in contrast, reports on the importance of firm size.

There are several reasons why large exporters are more likely to set different prices in different markets than small exporters. ${ }^{2}$ First, large exporters tend to sell to more markets, whereas small firms frequently concentrate on a single market or buyer. ${ }^{3}$ The more markets a firms supplies, the greater is the likelihood that there is at least one market with sufficiently distinct characteristics to induce the firm to charge a market-specific price different from that in other markets. Second, large exporters are more likely to have sufficient market power to set prices. Third, larger exporting firms are more likely to incur the transaction costs associated with international price discrimination. Such costs are not usually addressed in the theoretical lit-

\footnotetext{
${ }^{1}$ Obstfeld and Rogoff (2000), Engel (2000) and Devereux and Engel (2003) are just a few examples.

${ }^{2}$ These are also linked with Varian's (1989) necessary conditions for price discrimination to be a solution to the firm's maximization problem: (i) sorting of customers, (ii) prevention of resale, and (iii) the presence of market power.

${ }^{3}$ Eaton et al. (2004), for instance, show that in a sample of French manufacturing firms more than a third export to one market only. Counting only those firms that export at all, more than $60 \%$ export to one market only.
} 
erature, but matter in practice, since international price discrimination requires detailed knowledge of local market conditions. Moreover, by investing in market-specific branding and marketing, firms can influence the degree of market segmentation (Friberg, 2001), which itself is a precondition for price discrimination. Since the investment in both information gathering and segmentation is largely independent of sales volumes and thus more like a fixed than a variable cost, larger firms will be more frequently willing to undertake it. $^{4}$

To test the hypothesis that firm-specific factors, in particular firm size, are important determinants of international price discrimination, we use crosssectional information from a recent survey of Swiss exporters. While there are a handful of studies that address questions related to international price segmentation on the basis of survey data, little emphasis has been placed on firm size. ${ }^{5}$ The Swiss survey asked exporters whether they set different prices across their export markets and, if so, whether price segmentation occurred because of pricing conditions in the local market or other factors. The econometric analysis of their responses presented in this paper uses a probit model to regress a binary-choice variable of international price discrimination on firm size and other control variables. As in the original literature on international price discrimination (e.g. Krugman 1987), we refer to this phe-

\footnotetext{
${ }^{4} \mathrm{~A}$ related 'stylized fact' that has sometimes been attributed to transaction costs is the positive correlation between firm size and export intensity (see Avenir Suisse 2005 for evidence on this correlation for Switzerland). Several recent contributions, however, suggest that this relationship may be driven by other firm-specific factors (see, e.g., Verwaal and Donkers 2002; Wagner 2003 and Kalafsky 2004).

${ }^{5}$ See Friberg and Wilander (2007) and the studies listed in Fabiani et al. (2007). One exception is Lünnemann and Mathä (2006, Table 5) who show that, in the case of Luxembourg, larger firms set different prices across countries more frequently than smaller firms, but this result is not tested econometrically.
} 
nomenon as pricing-to-markets (PTM). In principle, this is compatible with both producer- and local-currency pricing (PCP and LCP, respectively).

\section{Data and PTM Variables}

Information on the pricing behavior of Swiss exporters is taken from the 2006 Survey on Export Pricing conducted by the KOF Swiss Economic Institute at the request of the Swiss National Bank. This one-off questionnaire on export pricing was distributed as part of the regular quarterly KOF Economic Barometer surveys. ${ }^{6}$ In addition to price segmentation, the survey asked questions on export destination, market share, type of buyer and currency invoicing. The survey was sent to 1421 firms in industry, services (hotel and restaurant) and the financial sector, located throughout Switzerland in August 2006. In this paper, we focus solely on the 826 firms in the industrial sector included in the survey. Among these industrial firms, 543 responded, corresponding to a response rate of $65.7 \%$.

The construction of the binary choice variable for PTM is based on two questions in the survey. The first asks: If your firm's main export product in 2005 was delivered to different export destinations, did the price measured in CHF differ between these markets? Of the 531 valid responses from industrial firms to this question (i.e., 12 of the 543 did not respond to this question), $50.5 \%$ answered affirmatively. ${ }^{7}$ This figure is practically identical to that found for the four countries where the same question was asked in

\footnotetext{
${ }^{6}$ The survey is based on a random sample, stratified by firm size and sectors. The questionnaire on export pricing was only sent to those firms that actually export.

${ }^{7}$ Note that the question refered to the price received by the exporting firm. Depending on who the product was sold to, it could be a price at the border or a consumer price.
} 
the recent Euro-area price-setting surveys (Fabiani et al. 2006). If the survey respondent answered yes, a second question sought to identify whether price segmentation resulted from differences in costs or pricing conditions across national markets. The exporters were asked to state whether the following factors were either very important, somewhat important, or unimportant in explaining price differences across export markets: exchange rate fluctuations, transport costs, local costs (i.e., for product adaptation, marketing, import duties, regulation, taxes etc.), prices of competitors, copyright and/or patent protection, buyer preferences, and income differences.

Table 1 presents the responses to the second question on price segmentation. The most important reason for price differences across markets was 'prices of competitors'. The next most frequently cited reasons were buyer preferences, transport costs, exchange rate fluctuations and local costs, which at least $20 \%$ of firms deemed to be very important. Few firms cited patents and income differences as very important. ${ }^{8}$ This indicates that the standard textbook model of price discrimination where firms discriminate between different income groups is not particularly relevant in this dataset.

The survey also asked firms to indicate in which currrencies they invoiced their customers in their main export market. While the invoicing currency does not necessarily have to correspond to the price-setting currency, empirical evidence suggests that the two are usually the same (Friberg and Wilander 2006). Interestingly, $52 \%$ of the firms in our sample indicated that they used a mix of LCP and PCP in their main export market. Of the rest,

\footnotetext{
${ }^{8}$ 'Prices of competitors' was also the most important reason for price differences in the Euro-area price-setting surveys (Fabiani et al. 2006).
} 
$28.4 \%$ were pure LCP setters and $16.6 \%$ pure PCP setters. ${ }^{9}$ Price differences across export markets are thus not just limited to LCP firms. ${ }^{10}$

We use two definitions of PTM to construct our binary PTM variable. The first, PTM-1, narrowly includes only those firms that cited 'prices of competitors' as 'very important'. The second definition, PTM-2, is somewhat wider and includes all those firms that considered either "prices of competitors', 'exchange rate fluctuations', 'buyer preferences' or 'income differences' as 'very important'. As a result, 190 firms are classified as PTM-1 and 220 as PTM-2, out of a total of 531. In the next section, both variables are regressed on firm-specific factors and other control variables to determine the relationship between firm structure and PTM. ${ }^{11}$

\section{Empirical Results}

To determine if PTM is coincident with firm size, we regress the following probit specification:

$$
\operatorname{Pr}(P T M=1 \mid \mathbf{x})=\Phi\left(\mathbf{x}^{\prime} \boldsymbol{\beta}\right)
$$

\footnotetext{
${ }^{9}$ The remainder invoiced in vehicle currencies. Note that the survey questions were specifically addressed at the main export market. We thus do not have information on whether the prevalence of dual pricing behavior (i.e., PCP and LCP), strict PCP vs. LCP or of vehicle currencies applies to other export markets.

${ }^{10}$ Focusing strictly on LCP firms would have also meant dropping more than two-thirds of the sample observations.

${ }^{11}$ We also performed our estimation with an even wider categorization, by classifying all firms that price-segment as PTM. This yielded qualitatively similar results to those presented here.
} 
where the dependent variable, $P T M$, is +1 if firm $i$ price discriminates between markets according to one of our two definitions, 0 otherwise, the function $\Phi($.$) denotes the standard normal distribution, and \mathbf{x}$ contains the explanatory variables. Our key explanatory variable is firm size, which is measured as the log of the number of employees. As additional controls, we include sectoral dummy variables, export intensity, export market share and distance from the border. The sectoral dummies take account of unobservable industry-specific differences in PTM behavior. Export intensity (i.e., the share of exports in firm revenue) helps us control for the often observed positive correlation with firm size (see footnote 2). Without it, our measure of firm size might indirectly capture the influence of export intensity on PTM behavior. Export market share controls for the degree of market power in the destination market. ${ }^{12}$ Distance from the border is included since firms closer to the border might find it easier to collect the information necessary for PTM. Equation (1) should not be interpreted as a structural equation. Rather, we are interested in the coincidence between firm size and PTM, in particular whether larger firms are more likely to price their products to the local market than smaller firms.

Table 2 presents four pairs of regression results. Each pair relates to the same specification but for the two alternative PTM classifications. The first pair, presented in columns (1.1) and (1.2), shows the results of a simple regression between PTM and firm size. The second pair, in columns (2.1) and

\footnotetext{
${ }^{12}$ Both, export intensity and export market share are based on categorical data. Export intensity is provided by KOF as a three-way categorical measure (exports relative to sales revenue of $<33 \%, 34-66 \%$ and $>66 \%$ ). Export market share comes directly from the survey: firms were asked to place their firm's share in one of five categories $(<1 \%, 1-5 \%, 6-25 \%$, $26-50 \%$, and $>50 \%$ ).
} 
(2.2), contains the additional control variables. In each of these four regressions, the coefficient on firm size is positive and significant at the $5 \%$ critical level. Export intensity and distance to the border have the expected sign, but are mostly insignificant. Export market share and the sectoral dummies (not shown) are not significant in any of our specifications. ${ }^{13}$

To determine if our results are driven by firms in particular sectors, we also divided firm size by its SIC 2-digit industrial classification, and performed a likelihood ratio test on the sector-specific coefficients on firm size. The sectoral classifications are chemistry and plastics (97 observations); metals (98); machinery (113); electric, electronic, and precision instruments (110); and other sectors (125). The p-values indicate that the null hypothesis of equality cannot be rejected at the five percent level. We therefore interpret the Swiss evidence in the first four columns of Table 2 as follows: the positive coincidence between firm size and PTM is robust across industrial sectors, our two PTM classifications, and different regression specifications.

Next, to control for export destination, we examined whether there are systematic differences between firms that listed a country in the Euro area as their 'main export market' and those that listed other destinations. ${ }^{14}$ This data cut takes account of the proposition that PTM behavior is less likely within a currency union. ${ }^{15}$ The corresponding results are presented in the

\footnotetext{
${ }^{13}$ In other versions of our regression model (not reported here) we also included the share of exports sold the company group (also part of the export pricing suvey) to capture posible differences between arm's-length transactions and trade within multinational firms (see Hellerstein and Villas-Boas 2006) However, this variable proved to be insignificant throughout.

${ }^{14}$ The survey questions related to the firms' 'main export market' only. Nearly $73 \%$ percent of industrial firms in the survey had their main export market in the Euro area.

${ }^{15}$ Several arguments have been put forth. The European Commission has, for instance, frequently argued in the run-up to the Euro that a common currency raises transparency
} 
last four columns of Table 2. Again, columns (3.1) and (3.2) are without the additional control variables and columns (4.1) and (4.2) include them. The main result holds: firm size is positively and significantly correlated with the likelihood of PTM. The estimated coefficient is more than twice as large for firms whose main export market is in the Euro area, suggesting that firm size could be an even more important determinant of PTM within a currency union, but the difference is not statistically significant (see the row labeled 'Euro area versus non-Euro area firm size (p-value)'). The Euro-area dummy has a negative sign, which is in line with the prediction that PTM is ceteris paribus less prevalent within a currency union, but it is only significant at the ten percent level. The other results are similar to those in the first four columns of Table 2: the additional control variables have the expected sign but remain mostly insignificant; the correlation between firm size and PTM does not vary across sectors; and there is little difference between the results for the two PTM classifications.

\section{Concluding remarks}

The results in this paper show that firm-specific factors explain why some exporters pursue PTM strategies and others do not. In particular, we find a positive relationship between PTM and firm size using survey evidence on

and comparability for consumers. This implies greater arbitrage opportunities and thus reduces a firm's ability to PTM. Friberg (2001) shows that a common currency lowers the incentive for firms to invest in the market segmentation necessary for PTM. Devereux et al. (2003) argue that third-country exporters will tend to view a monetary union as a single marketing area and therefore charge a common price. Bacchetta and van Wincoop (2005) show that a monetary union will tend to make exporting firms in these countries invoice in the local currency of a third country. 
Swiss exporters. The correlation is robust across a range of specifications. We also find that while firms whose main export market is in the Euro area are less likely to engage in PTM, firm size plays a bigger role for them.

It is important to note that our evidence on the determinants of PTM should not be generalized to the degree of exchange rate pass-through (EPT). PTM is a necessary pre-condition for incomplete EPT, but not a sufficient one (Goldberg and Knetter 1997). However, it is possible that the same determinants apply to both PTM and EPT. If true, and firm size is also related to the degree of EPT, then differences in the distribution of firm size could be yet another explanation for why EPT appears to both differ across sectors and markets, and vary over time. 


\section{References}

Avenir Suisse, 2005, Die Warenexporte der Schweiz und Österreichs im Vergleich. (Avenir Suisse, Zürich).

Bacchetta, P.and E. van Wincoop, 2005, A theory of the currency denomination of international trade, Journal of International Economics 67, 295-319.

Devereux, M.B. and C. Engel, 2003, Monetary policy in the open economy revisited: price setting and exchange-rate flexibility, Review of Economic Studies $70,765-783$.

Devereux, M.B., C. Engel and C. Tille, 2003, Exchange rate pass-through and the welfare effects of the Euro, International Economic Review 44, 223-242.

Eaton, J , S. Kortum and F. Kramarz, 2004, Dissecting trade: firms, industries and export destinations, American Economic Review 94, 150-154.

Engel, C., 2000, Local-currency pricing and the choice of exchange-rate regime, European Economic Review 44, 1449-1472.

Fabiani, S., M. Druant, I. Hernando, C. Kwapil, B. Landau, C. Loupais, F. Martins, T. Matha, R. Sabbatini, H. Stahl, and A. Stokman, 2006, What firms' surveys tell us about price-setting behavior in the Euro area, International Journal of Central Banking 2(3), 3-48.

Fischer, A.M., M. Lutz, and M. Wälti, 2007, Export pricing of Swiss firms, Swiss National Bank, mimeo.

Friberg, R., 2001, Two Monies, Two Markets? Variability and the option to segment, Journal of International Economics 55, 317-327.

Friberg, R., and F. Wilander, 2007, The currency denomination of exports a questionnaire study, University of Stockholm, mimeo.

Goldberg, P.K. and M.M. Knetter, 1997, Goods prices and exchange rates: what have we learned? Journal of Economic Literature 35, 1243-72.

Hellerstein, R. and S.B. Villas-Boas, 2006, Arm's-length transactions as a source of incomplete cross-border transmission: the case of autos, Federal Reserve Bank of New York Staff Reports, no. 251, April.

Kalafsky, R., 2004, Export activity and firm size: an examination of the machine tool sector, Journal of Small Business and Enterprise Development $11,159-165$.

Knetter, M., 1989, Price discrimination by U.S. and German exporters, American Economic Review 79, 198-210. 
Krugman, P., 1987, Pricing to market when the exchange rate changes, in: S.V. Arndt and J.D. Richardson, eds., Real-Financial Linkages Among Open Economies (MIT Press, Cambridge) 49-70.

Lünnemann, P and T. Mathä, 2006, New survey evidence on the pricing behaviour of Luxembourg firms, Working Paper 617, European Central Bank, May.

Obstfeld, M. and K. Rogoff, 2000, New directions for stochastic open economy models, Journal of International Economics 50, 117-153.

Varian, H., 1989, Price discrimination, in: R. Schmalensee and R.D. Willig, eds., Handbook of Industrial Organization, Vol. 1, (North-Holland, Amsterdam) 597-654.

Verwaal, E. and B. Donkers, 2002, Firm size and export intensity: solving an empirical puzzle 35, Journal of International Business Studies 3, 603-613.

Wagner, J. 2003, Unobserved firm heterogeneity and the size-exports nexus: evidence from German panel data, Review of World Economics 139, 161-172. 
Table 1: Why does price segmentation occur?

\begin{tabular}{|l|ccc|}
\hline & Very & Somewhat & Not \\
& important & important & important \\
\hline Exchange rate fluctuations & $24.8 \%$ & $47.2 \%$ & $28.0 \%$ \\
Transport costs & $26.2 \%$ & $50.8 \%$ & $23.1 \%$ \\
Costs in local market & $21.5 \%$ & $47.0 \%$ & $31.6 \%$ \\
Prices of competitors & $74.5 \%$ & $21.2 \%$ & $4.3 \%$ \\
Copyright/patent protection & $5.3 \%$ & $21.0 \%$ & $73.7 \%$ \\
Buyer preferences & $29.0 \%$ & $45.6 \%$ & $25.4 \%$ \\
Income differences & $11.3 \%$ & $31.3 \%$ & $57.5 \%$ \\
\hline
\end{tabular}

Notes: The table summarizes the responses of the 531 firms in our sample that set different prices across export markets. Multiple answers were permitted. 
Table 2: Probit regressions of PTM on firm size

\begin{tabular}{|c|c|c|c|c|c|c|c|c|}
\hline PTM classification & $\begin{array}{c}1.1 \\
\text { PTM-1 }\end{array}$ & $\begin{array}{c}1.2 \\
\text { PTM-2 }\end{array}$ & $\begin{array}{c}2.1 \\
\text { PTM-1 }\end{array}$ & $\begin{array}{c}2.2 \\
\text { PTM-2 }\end{array}$ & $\begin{array}{c}3.1 \\
\text { PTM-1 }\end{array}$ & $\begin{array}{c}3.2 \\
\text { PTM-2 }\end{array}$ & $\begin{array}{c}4.1 \\
\text { PTM-1 }\end{array}$ & $\begin{array}{c}4.2 \\
\text { PTM-2 }\end{array}$ \\
\hline Euro area dummy & & & & & $\begin{array}{c}-0.757^{+} \\
(0.435)\end{array}$ & $\begin{array}{c}-0.799^{+} \\
(0.418)\end{array}$ & $\begin{array}{l}-0.606 \\
(0.451)\end{array}$ & $\begin{array}{c}-0.652 \\
(0.434)\end{array}$ \\
\hline Firm size (all) & $\begin{array}{l}0.238^{*} \\
(0.045)\end{array}$ & $\begin{array}{l}0.229 * \\
(0.043)\end{array}$ & $\begin{array}{l}0.232 * \\
(0.047)\end{array}$ & $\begin{array}{l}0.217^{*} \\
(0.046)\end{array}$ & & & & \\
\hline Firm size (Euro area) & & & & & $\begin{array}{l}0.286^{*} \\
(0.055)\end{array}$ & $\begin{array}{l}0.274^{*} \\
(0.053)\end{array}$ & $\begin{array}{l}0.275^{*} \\
(0.059)\end{array}$ & $\begin{array}{c}0.256^{*} \\
(0.057)\end{array}$ \\
\hline Firm size (non-Euro area) & & & & & $\begin{array}{l}0.141^{+} \\
(0.077)\end{array}$ & $\begin{array}{l}0.128^{+} \\
(0.074)\end{array}$ & $\begin{array}{c}0.157 \\
(0.078)\end{array}$ & $\begin{array}{l}0.139^{+} \\
(0.076)\end{array}$ \\
\hline Export market share & & & $\begin{array}{c}-0.065 \\
(0.051)\end{array}$ & $\begin{array}{l}-0.036 \\
(0.050)\end{array}$ & & & $\begin{array}{l}-0.071 \\
(0.052)\end{array}$ & $\begin{array}{c}-0.046 \\
(0.051)\end{array}$ \\
\hline Export intensity & & & $\begin{array}{c}0.126 \\
(0.081)\end{array}$ & $\begin{array}{l}0.154^{+} \\
(0.080)\end{array}$ & & & $\begin{array}{c}0.117 \\
(0.081)\end{array}$ & $\begin{array}{l}0.144^{+} \\
(0.080)\end{array}$ \\
\hline Distance to border & & & $\begin{array}{l}-0.252 \\
(0.202)\end{array}$ & $\begin{array}{l}-0.163 \\
(0.192)\end{array}$ & & & $\begin{array}{l}-0.246 \\
(0.203)\end{array}$ & $\begin{array}{c}-0.160 \\
(0.193)\end{array}$ \\
\hline Sectoral dummies (p-value) & & & 0.932 & 0.796 & & & 0.917 & 0.773 \\
\hline $\begin{array}{r}\text { Firm size by sectors (p-value) } \\
\text { all } \\
\text { Euro area } \\
\text { non-Euro area }\end{array}$ & 0.933 & 0.947 & 0.461 & 0.733 & $\begin{array}{l}0.182 \\
0.791\end{array}$ & $\begin{array}{l}0.557 \\
0.726\end{array}$ & $\begin{array}{l}0.187 \\
0.627\end{array}$ & $\begin{array}{l}0.662 \\
0.701\end{array}$ \\
\hline Euro effect (p-value) & & & & & 0.191 & 0.121 & 0.277 & 0.816 \\
\hline $\begin{array}{l}\text { DOF } \\
\text { Cases correct } \\
\text { Pseudo } R^{2}\end{array}$ & $\begin{array}{c}516 \\
347 \\
0.057\end{array}$ & $\begin{array}{c}521 \\
320 \\
0.054\end{array}$ & $\begin{array}{c}486 \\
326 \\
0.066\end{array}$ & $\begin{array}{c}490 \\
306 \\
0.064\end{array}$ & $\begin{array}{c}514 \\
352 \\
0.063\end{array}$ & $\begin{array}{c}519 \\
319 \\
0.062\end{array}$ & $\begin{array}{c}484 \\
323 \\
0.070\end{array}$ & $\begin{array}{c}488 \\
305 \\
0.069\end{array}$ \\
\hline
\end{tabular}

Notes: Standard errors (robust) are shown in parentheses. DOF denotes degrees of freedom,

* significance at the $5 \%$ and ${ }^{+}$significance at the $10 \%$ level. The p-values refer to likelihood ratio tests. PTM-1 and PTM-2 are the two classifications described in the text. Each regression also contains a constant term (not shown). 


\section{Swiss National Bank Working Papers published since 2004:}

2004-1 Samuel Reynard: Financial Market Participation and the Apparent Instability of Money Demand

2004-2 Urs W. Birchler and Diana Hancock: What Does the Yield on Subordinated Bank Debt Measure?

2005-1 Hasan Bakhshi, Hashmat Khan and Barbara Rudolf: The Phillips curve under state-dependent pricing

2005-2 Andreas M. Fischer: On the Inadequacy of Newswire Reports for Empirical Research on Foreign Exchange Interventions

2006-1 Andreas M. Fischer: Measuring Income Elasticity for Swiss Money Demand: What do the Cantons say about Financial Innovation?

2006-2 Charlotte Christiansen and Angelo Ranaldo: Realized Bond-Stock Correlation: Macroeconomic Announcement Effects

2006-3 Martin Brown and Christian Zehnder: Credit Reporting, Relationship Banking, and Loan Repayment

2006-4 Hansjörg Lehmann and Michael Manz: The Exposure of Swiss Banks to Macroeconomic Shocks - an Empirical Investigation

2006-5 Katrin Assenmacher-Wesche and Stefan Gerlach: Money Growth, Output Gaps and Inflation at Low and High Frequency: Spectral Estimates for Switzerland

2006-6 Marlene Amstad and Andreas M. Fischer: Time-Varying Pass-Through from Import Prices to Consumer Prices: Evidence from an Event Study with Real-Time Data

2006-7 Samuel Reynard: Money and the Great Disinflation

2006-8 Urs W. Birchler and Matteo Facchinetti: Can bank supervisors rely on market data? A critical assessment from a Swiss perspective

2006-9 Petra Gerlach-Kristen: A Two-Pillar Phillips Curve for Switzerland

2006-10 Kevin J. Fox and Mathias Zurlinden: On Understanding Sources of Growth and Output Gaps for Switzerland

2006-11 Angelo Ranaldo: Intraday Market Dynamics Around Public Information Arrivals

2007-1 Andreas M. Fischer, Gulzina Isakova and Ulan Termechikov: Do FX traders in Bishkek have similar perceptions to their London colleagues? Survey evidence of market practitioners' views 
2007-2 Ibrahim Chowdhury and Andreas Schabert: Federal Reserve Policy viewed through a Money Supply Lens

2007-3 Angelo Ranaldo: Segmentation and Time-of-Day Patterns in Foreign Exchange Markets

2007-4 Jürg M. Blum: Why ‘Basel II’ May Need a Leverage Ratio Restriction

2007-5 Samuel Reynard: Maintaining Low Inflation: Money, Interest Rates, and Policy Stance

2007-6 Rina Rosenblatt-Wisch: Loss Aversion in Aggregate Macroeconomic Time Series

2007-7 Martin Brown, Maria Rueda Maurer, Tamara Pak and Nurlanbek Tynaev: Banking Sector Reform and Interest Rates in Transition Economies: Bank-Level Evidence from Kyrgyzstan

2007-8 Hans-Jürg Büttler: An Orthogonal Polynomial Approach to Estimate the Term Structure of Interest Rates

2007-9 Raphael Auer: The Colonial Origins Of Comparative Development: Comment. A Solution to the Settler Mortality Debate

2007-10 Franziska Bignasca and Enzo Rossi: Applying the Hirose-Kamada filter to Swiss data: Output gap and exchange rate pass-through estimates

2007-11 Angelo Ranaldo and Enzo Rossi: The reaction of asset markets to Swiss National Bank communication

2007-12 Lukas Burkhard and Andreas M. Fischer: Communicating Policy Options at the Zero Bound

2007-13 Katrin Assenmacher-Wesche, Stefan Gerlach, and Toshitaka Sekine: Monetary Factors and Inflation in Japan

2007-14 Jean-Marc Natal and Nicolas Stoffels: Globalization, markups and the natural rate of interest

2007-15 Martin Brown, Tullio Jappelli and Marco Pagano: Information Sharing and Credit: Firm-Level Evidence from Transition Countries

2007-16 Andreas M. Fischer, Matthias Lutz and Manuel Wälti: Who Prices Locally? Survey Evidence of Swiss Exporters 
Swiss National Bank Working Papers are also available at www.snb.ch, section Publications/Research Subscriptions or individual issues can be ordered at Swiss National Bank, Fraumünsterstrasse 8, CH-8022 Zurich, fax+41 4463181 14, E-mail library@snb.ch 